NBER WORKING PAPER SERIES

\title{
TESTING THE THEORY OF TRADE POLICY: \\ EVIDENCE FROM THE ABRUPT END OF THE MULTIFIBRE ARRANGEMENT
}

\author{
James Harrigan \\ Geoffrey Barrows \\ Working Paper 12579 \\ http://www.nber.org/papers/w12579
NATIONAL BUREAU OF ECONOMIC RESEARCH
1050 Massachusetts Avenue
Cambridge, MA 02138
October 2006

International Research Department, Federal Reserve Bank of New York, 33 Liberty Street, New York NY 10045. Corresponding author is James Harrigan, james.harrigan@ ny.frb.org. This paper is a substantially revised version of our October 2006 NBER Working Paper no. 12579 of the same name. We thank Deirdre Daly for help with the data, and Yue Li and seminar participants at the World Bank and the New York Fed for helpful comments. The views expressed in this paper are those of the authors and do not necessarily reflect the position of the Federal Reserve Bank of New York or the Federal Reserve System. The views expressed herein are those of the author(s) and do not necessarily reflect the views of the National Bureau of Economic Research.

(C) 2006 by James Harrigan and Geoffrey Barrows. All rights reserved. Short sections of text, not to exceed two paragraphs, may be quoted without explicit permission provided that full credit, including (c) notice, is given to the source. 
Testing the Theory of Trade Policy: Evidence from the Abrupt End of the Multifibre Arrangement James Harrigan and Geoffrey Barrows

NBER Working Paper No. 12579

October 2006

JEL No. F1,F13,F14

\begin{abstract}
$\underline{\text { ABSTRACT }}$
Quota restrictions on United States imports of apparel and textiles under the multifibre arrangement (MFA) ended abruptly in January 2005. This change in policy was large, predetermined, and fully anticipated, making it an ideal natural experiment for testing the theory of trade policy. We focus on simple and robust theory predictions about the effects of binding quotas, and also compute nonparametric estimates of the cost of the MFA. We find that prices of quota constrained categories from China fell by $38 \%$ in 2005, while prices in unconstrained categories from China and from other countries changed little. We also find substantial quality downgrading in imports from China in previously constrained categories, as predicted by theory. The annual cost of the MFA to U.S. consumers was about $\$ 90$ per household.
\end{abstract}

James Harrigan

International Research Department

Federal Reserve Bank-New York

33 Liberty Street

New York, NY 10045

and NBER

james.harrigan@ny.frb.org

Geoffrey Barrows

International Research Department

33 Liberty Street

New York, NY 10045

geoffrey.barrows@gmail.com 


\section{INTRODUCTION}

The economic analysis of trade policy is as old as economics, but the ratio of convincing evidence to theory remains small. ${ }^{1}$ The reason is simple: trade policies generally change gradually, making it hard to untangle the effects of policy from the effects of other factors that influence trade. A related empirical problem, highlighted by Trefler (1993), is the political endogeneity of protection, which creates the need for valid instrumental variables for protection in most analyses of the effects of trade policy.

This paper uses a natural experiment in U.S. trade policy to get around these thorny inference problems. The system of bilateral quotas long known as the multifibre arrangement (MFA) regulated global trade in apparel and textiles for many decades, and a major achievement of the Uruguay Round concluded in 1995 was that WTO members agreed to phase out MFA quotas no later than January 1, 2005². Like most big importers, the U.S. delayed the bulk of MFA liberalization until literally the last moment, with hundreds of binding quotas still in place until midnight on December 31 2004. As the new year dawned, a veritable tsunami of cheap textile and apparel products from China and other developing countries started to swamp U.S. ports. This large, sudden, fully anticipated, easily measured, and statistically exogenous change in trade policy provides the natural experiment that we use in this paper to test some simple theories about the effects of quotas.

We test two fundamental predictions: binding quotas raise prices and lead to "quality upgrading", that is, a shift in the mix of products under a given quota toward more expensive goods. These predictions are resoundingly confirmed: when the MFA ended, prices and quality of U.S. imports in previously quota-constrained categories fell dramatically, especially on quota-constrained goods from China. By contrast, nonconstrained imports showed no systematic changes in prices or quality. These results are highly robust, and require no restrictive assumptions on functional form or exogeneity.

\footnotetext{
${ }^{1}$ The ratio is not zero, however. See Feenstra (1995) for an excellent survey. Much high-quality work on the effects of trade policy is done at the World Bank; see for example Laird and Yeats (1990) and Kee et al (2006). The NAFTA agreement has occasioned some fine ex post analyses, including Trefler (2004) and Romalis (2005).

${ }^{2}$ When the Uruguay round was agreed, the MFA was replaced by the "Agreement on Textiles and Clothing" or ATC. To keep acronym profusion in check, we will continue to use the older term MFA in the remainder of this paper.
} 
We are also able to calculate estimates of what the MFA cost U.S. consumers in 2004: the equivalent variation was approximately $\$ 9.8$ billion, which amounts to an annual cost per household of almost $\$ 90$. Most of this welfare gain was due to the dramatic drop in prices, and increase in quantities, from China.

The end of the MFA, and the consequent unleashing of China's vast potential for producing cheap labor intensive textile and apparel products, was widely predicted to lead to calamity for other developing country textile and apparel exporters. We show that these fears were not borne out, at least for big exporters to the United States. The reason is that most of the big exporters were also quota constrained in 2004, and were able to sharply increase their exports when the MFA ended despite intensified competition from China. The major exception is Mexico, whose privileged access to the U.S. market ended with the end of the MFA.

\section{U.S. TRADE POLICY IN APPAREL AND TEXTILES}

A variety of restrictions have long affected trade in textile and apparel products. ${ }^{3}$ One of the broadest sets of policies, however, became effective in 1974. The MFA established a system of quotas, negotiated bilaterally, that limited imports of textile and apparel products.

Participants in the Uruguay Round of trade talks agreed to phase out the MFA beginning in 1995. The MFA was replaced by the Agreement on Textiles and Clothing (ATC) which put in place a system for gradual elimination of quantitative restrictions. The ATC incorporated a series of stages, with phase-outs occurring at the beginning of 1995, 1998, 2002, and 2005, at which time all remaining quotas were eliminated. Between 1995 and 2005, remaining quotas were progressively enlarged, using agreed-to increasing growth rates. The agreement also established a special safeguard mechanism for protection against surges and a monitoring body to supervise implementation.

When the MFA first came into effect, China was not a member of the World Trade Organization (WTO), so it was not a part of the initial MFA phase-out process. However, upon accession to the WTO at the end of 2001, China became eligible for participation in the MFA quota elimination process. Thus, the United States generally 
implemented the first three stages of "integration" (i.e., into the MFA quota liberalization program) for China in the first part of 2002. ${ }^{4}$ When it joined the WTO, China also agreed to a special safeguard on its textile and apparel exports. Under this safeguard mechanism, if a WTO member felt that textile and apparel imports from China threatened to "impede the orderly development of trade in these products," it could request that China limit its exports to that country, generally for no more than one year. If consultations did not lead to a different solution, China would agree to hold its exports of the given product "to a level no greater than 7.5 per cent (6 per cent for wool product categories) above the amount entered during the first 12 months of the most recent 14 months preceding the month in which the request for consultations was made.” This safeguard mechanism will remain in place until December 31, 2008. As we will discuss below, there was one such safeguard quota in effect on U.S. imports from China in 2005 even after all MFA quotas were eliminated on January 1, and twelve new safeguard quotas were imposed in mid-2005. For more on how the ATC was implemented, with a particular focus on China, see Brambilla, Khandelwal, and Schott (2007).

The MFA was not the only U.S. trade policy that affected apparel and textile trade in 2000-2005. However, these other policies saw no significant change between 2004 and 2005. Since our empirical analysis below looks exclusively at time-series variation during this period, we mention these other policies only briefly here.

In addition to agreeing to eliminate quantitative restrictions as part of the implementation of the Uruguay Round, the United States agreed to reduce its tariffs on textile and apparel products. According to the Office of Textiles and Apparel (OTEXA, a division of the U.S. Commerce Department that administers the US's MFA quotas) tariffs on textile and apparel products were slated to decline from a trade weighted average of 17.2 percent ad valorem in 1994 to a trade weighted average of 15.2 percent ad valorem in 2004. The majority of these reductions were phased in over the 10 years. ${ }^{5}$

\footnotetext{
3 The analysis in this section is based on Evans and Harrigan (2005).

${ }^{4}$ See Federal Register, Volume 66, No. 249, December 28, 2001; Federal Register, Volume 67, No. 53, March 19, 2002; WTO (2001) "Report of the Working Party on the Accession of China." WT/MIN(01)/3, November 10, 2001; and International Trade Commission (2004) "Textiles and Apparel: Assessment of the Competitiveness of Certain Foreign Suppliers to the U.S. Market.” Investigation No. 332-448. USITC Publication 3671.

${ }^{5}$ See OTEXA 1995.
} 
Regional liberalization efforts have also affected the degree to which quantitative restrictions constrain trade. The main regional agreements affecting the period which we examine are the Caribbean Basin Initiative/ Caribbean Basin Economic Recovery Act (CBI/CBERA) and the North American Free Trade Agreement (NAFTA). ${ }^{6}$ The CBI/CBERA programs, initially enacted in the mid-1980s, provided preferential treatment for imports from twenty-four countries in that region. ${ }^{7}$

\section{THEORY: PRICE, QUALITY, AND WELFARE EFFECTS OF QUOTAS}

The specification of MFA quota limits always had two features:

1. They were fairly broad, potentially including many different products. Some examples are "Womens' and girls' dresses, cotton" and "Mens' and boys' sweaters, wool".

2. They were specified not in value terms but in terms of physical quantities (numbers of dresses, square meters of fabric, dozens of pairs of socks, etc). What does economic theory predict about the effects of such broad, quantity-specified quotas? ${ }^{8}$

Trivially, a binding quota will reduce the quantity of imports, but beyond this the effects depend on details of demand and market structure. Numerous authors have pointed out that no simple "tariff equivalents" exist for quotas except in the simplest of cases; for example, see Anderson (1988) and Feenstra (2004, Chapter 8). Some of the more interesting analyses of the economics of quotas occurs when markets are imperfectly competitive; see, for example, the celebrated paper of Krishna (1989). What virtually any model predicts is that binding quotas will raise prices. That is, in the absence of a binding quota, prices of the products imported under the quota would be lower.

A slightly subtler effect is that a binding quota on a broad category causes "quality upgrading”, a phenomenon first analyzed by Falvey (1979) and Rodriguez

\footnotetext{
${ }^{6}$ The Andean Trade Preference Act (ATPA) was another program that provided benefits that, in some cases, applied to trade in apparel. The (ATPA) was signed into law on December 4, 1991, but excluded many apparel products. Ineligible products included, "textile and apparel items subject to textile agreements on the date that the ATPA took effect." See Shelburne (2002).

${ }^{7}$ Note that benefits were subject to the countries satisfying certain conditions.
} 
(1979). ${ }^{9}$ Quality upgrading occurs when the quota causes the composition of imports to be tilted toward goods that would be relatively more expensive under free trade.

There are potentially two distinct types of quality upgrading: changes in characteristics of given varieties, and a shift in demand toward higher-quality varieties (see Feenstra (2004, Chapter 8) for details). The latter is what we study, and the economics is simple: with a physical quantity quota, firms set quota rents as the same dollar amount over marginal cost. This means that high cost/quality goods see their relative price fall, so relative quantities sold go up. ${ }^{10}$ Evidence of this type of quality upgrading is provided by Boorstein and Feenstra (1991) for quota-constrained U.S. steel imports in the 1970s. We will ignore within-variety change, which may be substantial. For example, Feenstra (1988) finds substantial within-model quality upgrading in response to the U.S. quota on Japanese cars in the mid-1980s. The two quality-upgrading effects are complementary, so our measure of quality upgrading will be a lower bound.

Quality upgrading is socially inefficient, and causes a welfare cost to quotas that would not be present under an equally restrictive tariff. Even in the absence of quality upgrading binding quotas will impose efficiency costs and will redistribute income. From the standpoint of importing country welfare, the MFA is particularly costly since it allows exporters to keep quota rents (Krishna and Tan, 1998). Calculating welfare costs of protection generally requires details about demand and supply, information that can be estimated imprecisely at best. However, the total effect of any policy (including a quota) on consumers can be computed using measures of equivalent and compensating variation. Letting a superscript 0 denote the pre-reform, quota-ridden equilibrium and a superscript 1 denote the post reform equilibrium, the standard definitions of equivalent and compensating variation are

$$
\begin{aligned}
& E V=\mu\left(\mathbf{p}^{0}, u^{1}\right)-\mu\left(\mathbf{p}^{1}, u^{1}\right)=\mu\left(\mathbf{p}^{0}, u^{1}\right)-\mathbf{p}^{1} \mathbf{x}^{1} \\
& C V=\mu\left(\mathbf{p}^{0}, u^{0}\right)-\mu\left(\mathbf{p}^{1}, u^{0}\right)=\mathbf{p}^{0} \mathbf{x}^{0}-\mu\left(\mathbf{p}^{1}, u^{0}\right)
\end{aligned}
$$

\footnotetext{
${ }^{8}$ An alternative type of quota is one where the value of imports is restricted rather than the physical quantity.

${ }^{9}$ The quality upgrading insight appears to have occurred to Falvey and Rodriguez independently, with each paper somewhat grudgingly citing the working paper version of the other.

${ }^{10}$ This is also known as the Alchian-Allen/Washington apples effect. See Hummels and Skiba (2004).
} 
where $u$ is utility in each situation, $\mu\left(\mathbf{p}^{a}, u^{b}\right)$ is minimal expenditure required at prices $\mathbf{p}^{\mathrm{a}}$ to attain utility $u^{b}$, and $\mathbf{x}$ is optimally chosen consumption. ${ }^{11}$ Thus, $E V$ uses post-reform utility levels to compare the two situations, and $C V$ uses pre-reform utility. $E V$ is the answer to the question, "how much money would consumers facing the new prices have to be given to be indifferent between the new and old prices?" $12 \mathrm{CV}$ is the answer to the question, "how much money would consumers facing the old prices be willing to pay to be indifferent between the new and old prices?”.

Calculation of $E V$ and $C V$ requires knowing the form of the expenditure function $\mu$, and in particular the full Hicksian cross-price elasticities across products and supplier countries, knowledge we do not have and can not plausibly estimate. A non-parametric solution to this problem is to take a first-order Taylor series approximation of the expenditure function evaluated at each situation. Deaton and Muellbauer (1980, section 7.4) show that

$$
\begin{aligned}
& C V \simeq \mathbf{q}^{0}\left(\mathbf{p}^{0}-\mathbf{p}^{1}\right) \\
& E V \simeq \mathbf{q}^{1}\left(\mathbf{p}^{0}-\mathbf{p}^{1}\right)
\end{aligned}
$$

These approximations are also quite intuitive. The first uses old quantities to weigh the price changes, while the second uses new quantities to weigh the same price changes.

$E V$ and $C V$ answer different questions, and so neither is an unambiguous measure of consumer welfare change. A compromise measure suggested by Deaton and Muellbauer is

$$
W=\frac{1}{2}\left(\mathbf{q}^{1}+\mathbf{q}^{0}\right)\left(\mathbf{p}^{0}-\mathbf{p}^{1}\right)
$$

The number $W$ uses an average of the quantities as weights for the price change, and is a first-order approximation to a simple average of the true $E V$ and true $C V$. While it has no direct welfare interpretation, we will use $W$ in our results as a convenient way of splitting the difference between $E V$ and $C V$.

The above calculations of $E V, C V$, and $W$ require the use of appropriate index

\footnotetext{
${ }^{11}$ Our exposition here follows Deaton and Muellbauer (1980, Chapter 7), except that we change the signs of $E V$ and $C V$ so that a positive number denotes welfare improvement.
} 
numbers, and when we implement them we will use the exact price index due to Feenstra (1994), which relies on the CES functional form for the subutility given by each group of goods over which the price index is calculated. Having made a functional form assumption for purposes of computing price indices, why do we not make an additional functional form assumption for combining prices into an expenditure function? The answer is that our approach in this paper is to make as few assumptions as necessary, and see what can be learned as a consequence. Any further precision in our results gained from assuming a functional form for the expenditure function would come solely from that assumption.

\section{DATA AND MEASUREMENT}

Our trade data come from the Census Bureau, and are analyzed at the 10-digit Harmonized System (HS) level, the most disaggregated classification available. Each import observation includes information on date, source country, value in dollars, and physical quantity (such as number of shirts).

Apparel and textile quotas are administered by the Office of Textiles and Apparel (OTEXA), a division of the Department of Commerce. Quotas apply to country-specific quota groups constructed by OTEXA and these quota groups contain multiple 10-digit HS codes ${ }^{13}$. From OTEXA we obtained information on annual quota levels from 2002 through 2005, as well as the fill rate, which is the proportion of the quota which was used by the end of each calendar year. For our empirical analysis we define a quota as binding if the fill rate is greater than or equal to $90 \%{ }^{14}$. In most cases non-binding quotas will

\footnotetext{
${ }^{12}$ Scotchmer (1989) shows that with uncertainty, compensation will have to be greater if consumers are risk averse. This consideration seems unlikely to be quantitatively important in the current context, where apparel is a small share of consumer budgets, so we set it aside in what follows.

${ }^{13}$ Within a given quota group, there may be multiple 3-digit OTEXA categories (also constructed by OTEXA) and within each of those, there may be multiple individual 10-digit HS10 codes. The quota groups are closely related to the 3-digit OTEXA categories, but do not necessarily aggregate the same categories for each country. Thus, there may be more quota groups in a given year than 3-digit categories, though the former is almost always coarser.

${ }^{14}$ Industry experts define a quota as restrictive or "constraining" if it is filled to between 85 and 90 percent. This is because complexities in the quota management system (including complex aggregates) can make it difficult to completely fill a quota. The EU defines quotas 95 percent filled as constraining. See USITC (2002). Evans and Harrigan (2005) provide evidence that the price effect of MFA quotas is a step function in the fill rate, with the step at about $90 \%$.
} 
have no effect on prices, but our welfare calculations are not affected by the assumption that quotas bind if and only if the fill rate is at least $90 \%$.

To illustrate the dimensions of the data, in 2005 the US imported goods in 173 quota groups and 3,704 10-digit HS codes from 193 countries. The total value of US imports in textile and apparel in 2005 was $\$ 97.5$ billion, or $4.8 \%$ of total US imports.

The simplest measure of prices that can be constructed from this data is unit value, which is defined as the total value of shipments divided by the physical quantity. That is, for each country and each quota group, the unit value in a given year is defined as

$$
U V_{c g t}=\frac{\sum_{i \in I_{c g t}} v_{c i t}}{\sum_{i \in I_{c g t}} x_{c i t}},
$$

where $v_{c i t}$ is the dollar value of imports of HS10 code $i$ in time $t$ from country $c, x_{c i t}$ is the quantity of imports, and $I_{c g t}$ is the set of HS10 codes in quota group $g$ imported in time $t$ from country $c$. We can re-write the definition of unit value to emphasize the fact that the unit value is a quantity-weighted average of the prices of individual goods:

$$
U V_{c g t}=\sum_{i \in I_{c g t}} \omega_{c i t} p_{c i t}, \quad \omega_{c i t}=\frac{x_{c i t}}{\sum_{i \in I_{c g t}} x_{c i t}}
$$

Equation (2) makes it clear that unit values for a given quota group-country can change over time even if all individual prices are unchanged: the set of goods can change, and/or the relative quantities consumed can change. This property is sufficient to demonstrate that changes in quota group unit values should not be used as measures of quota group price change. Feenstra (1994) proposes an exact price index which accounts for changes in the set of goods as well as changes in relative quantities consumed, and we adopt his methodology for constructing price indices in what follows.

Following Feenstra (1994), suppose that the expenditure function for textiles and apparel imports in a quota group $g$ from country $c$ is of the CES form, given by

$$
e\left(\mathbf{p}, I_{c g t}, \mathbf{b}\right)=\left[\sum_{i \in I_{c g t}} b_{i} p_{i t}^{1-\sigma}\right]^{\frac{1}{1-\sigma}}
$$


Aside from functional form there are three assumptions embedded in this specification which deserve comment. First, the index $i$ denotes an HS10 code-country combination, which means we assume that all goods from a certain country in a given HS10 code are perfect substitutes. Second, the taste parameters $\mathbf{b}$ do not change over time. Finally, the elasticity of substitution $\sigma>1$ is the same across goods within the quota group. As an aside, we note that we will be making no assumptions about how the higher-level expenditure function for overall textile and apparel imports relates to these expenditure functions for individual country-quota groups.

To develop the Feenstra price index we need to introduce some notation. Omitting the implicit $c g$ subscripts to reduce clutter, define

$I_{t}=$ set of goods imported in year $t$

$I_{t-1}=$ set of goods imported in year $t-1$

$I_{t,-1-1}=$ set of "overlap goods" imported in year $t$ and in year $t-1$

It will always be the case in our application that $I_{t, t-1}$ is non-empty; often we'll have no change in the set of goods imported, so $I_{t, t-1}=I_{t}=I_{t-1}$. Next, define

$$
\lambda_{t}=\frac{\sum_{i \in I_{t, t-1}} v_{i t}}{\sum_{i \in I_{t}} v_{i t}} \leq 1, \quad \lambda_{t-1}=\frac{\sum_{i \in I_{t, t-1}} v_{i t-1}}{\sum_{i \in I_{t-1}} v_{i t-1}} \leq 1
$$

so $\lambda_{\mathrm{t}}=$ (expenditure on overlap goods in $t$ )/(total expenditure in $t$ ). In most cases this fraction will be close to one. Then define

$$
\lambda_{t, t-1}=\frac{\lambda_{t}}{\lambda_{t-1}}
$$

This ratio of ratios can be greater than or less than one. If there isn't much product churning from period to period the numerator and denominator will both be close to one, so the ratio will be close to one as well.

With this notation established, we can introduce the exact price index $F$ associated with the expenditure function (3):

$$
\ln F\left(\mathbf{p}_{t}, \mathbf{p}_{t-1}, \mathbf{x}_{t}, \mathbf{x}_{t-1}\right)=\sum_{i \in I} w_{i t} \ln \frac{p_{i t}}{p_{i t-1}}+\frac{1}{\sigma-1} \ln \frac{\lambda_{t}}{\lambda_{t-1}}
$$

where $\sum_{i \in I} w_{i t}=1$ and $\sigma$ is an unknown parameter. The expenditure weights are given by 


$$
\begin{gathered}
s_{i t}=\frac{p_{i t} x_{i t}}{\sum_{i \in I} p_{i t} x_{i t}}=\frac{v_{i t}}{\sum_{i \in I} v_{i t}}=\frac{v_{i t}}{v_{t}} \\
w_{i t}=\frac{\left(s_{i t}-s_{i t-1}\right) \ln \frac{s_{i t-1}}{s_{i t}}}{\sum_{i \in I}\left(s_{i t}-s_{i t-1}\right) \ln \frac{s_{i t-1}}{s_{i t}}}
\end{gathered}
$$

(see Feenstra, 1994, equation (3)). This rather baroque expression for the weights can be understood more easily by noting that

$$
w_{i t} \simeq \frac{s_{i t}+s_{i t-1}}{2} \quad \text { and } \quad \lim _{\left(s_{i t}-s_{i t-1}\right) \rightarrow 0}\left[\left(s_{i t}-s_{i t-1}\right) \ln \frac{s_{i t-1}}{s_{i t}}\right]=s_{i t}
$$

which implies that the Feenstra index is very similar to a standard chain-weighted price index, with the most important wrinkle being that it accounts for new goods.

Following Boorstein and Feenstra (1991) among others, we can also calculate a quality index as the ratio of the unit value index to the exact price index for each quota group and exporter. The key difference between the unit value index and the exact price index is that the former uses physical quantity shares in each year as weights for the prices in forming the average price over the quota group, while the latter uses value share weights when forming the index. Expressed in logs, we have

$$
\ln \frac{Q_{t}}{Q_{t-1}}=\ln \frac{U V_{t}}{U V_{t-1}}-\ln F\left(\mathbf{p}_{t}, \mathbf{p}_{t-1}, \mathbf{x}_{t}, \mathbf{x}_{t-1}\right)
$$

The interpretation of (5) is that if the unit value index increase more than the exact price index, then the quality index rises, reflecting the fact that consumption has shifted towards more expensive goods within the category. We will call this phenomenon quality upgrading, and when it is reversed we will call it quality downgrading. It is worth emphasizing that quality change under this measure is purely a consequence of changes in consumption patterns, not changes in the quality of any individual goods within the category.

Finally, the definition of the Feenstra price index implicitly defines a measure of change in an index of real imports $X$,

$$
\ln \frac{X_{t}}{X_{t-1}}=\ln \frac{V_{t}}{V_{t-1}}-\ln F\left(\mathbf{p}_{t}, \mathbf{p}_{t-1}, \mathbf{x}_{t}, \mathbf{x}_{t-1}\right)
$$


where $V_{t}=\mathbf{p}_{t} \mathbf{x}_{t}$ is the nominal value of imports.

A reminder about notation is in order at this point. In equations (4), (5) and (6), we are constructing the exact price, quality and quantity indices over time for a particular exporting country $c$ and quota group $g$. This means, for example, that the vector $\mathbf{p}_{t}$ should be interpreted as $\mathbf{p}_{c g t}$. When we implement the welfare calculations described in equations (1), we will be summing the exact price indexes given by (4) multiplied by the quantity indices (6) over all country-quota group pairs.

To implement the price, quality and real imports indices defined by (4), (5) and (6) requires data on unit values and quantities of imports by country, time, and HS10 code, all data that we have. The Feenstra index (4) also requires an estimate of the elasticity of substitution $\sigma$ across products within a given quota group from a given country. Broda and Weinstein (2006) have calculated related elasticities using the estimation methodology developed by Feenstra (1994), but their results are not directly useable for our purposes. The reason is that the Broda-Weinstein elasticities refer to the substitution across countries of classes of goods that are much more aggregated than the quota groups that we use. Nonetheless, the Broda-Weinstein results are useful for getting an idea about plausible values of $\sigma$ for our purposes. For example, they report an elasticity of 3.02 for SITC 841, “MEN'S OR BOYS' COATS, JACKETS, SUITS, TROUSERS, SHIRTS, UNDERWEAR ETC. OF WOVEN TEXTILE FABRICS (EXCEPT SWIMWEAR AND COATED OR LAMINATED APPAREL), and this elasticity is representative of those that they find for other apparel and textile SITC codes $^{15}$. If we take 3 as a reasonable estimate of the cross-country elasticity of substitution for a broad apparel/textile category, it seems likely that the elasticity of substitution within countries for less broad categories would be higher. In the results that we report below we use $\sigma=5$ but our results are not at all sensitive to changing $\sigma$ in the range $[2,10]$. The reason for this insensitivity is simply that there is not much change over time in the set of goods imported within each quota group-country, so that the term $\ln \left(\frac{\lambda_{t}}{\lambda_{t-1}}\right)$ in the Feenstra index (4) is close to zero.

\footnotetext{
${ }^{15}$ The full list of elasticities is available on Broda's website, at http://faculty.chicagogsb.edu/christian.broda/website/research/unrestricted/Research.htm
} 
The empirical unimportance of the new goods adjustment in our application means that the Feenstra price index will be numerically very close to standard chainweighted indices such as the Törnqvist, which is an exact price index for the translog flexible functional form (in fact, when we do the calculations, the Feenstra and Törnqvist indices are identical to two decimal places).

\section{RESULTS}

For all U.S. imports of apparel and textiles and for every exporting country and quota group, we construct price, quality, and real import indices over time using (4), (5) and (6). While we have data beginning in 2002, we focus on the difference between 2004 and 2005, since the MFA expired on January 12005.

Even before the end of the MFA, a large majority of U.S apparel and textile imports were not subject to binding quotas: in 2004, only $17 \%$ of imports came in under a binding quota, a number that fell to 3.5\% in 2005. The reason that the quota share didn't fall to zero is that, as noted above, some quotas were re-imposed (mainly on China) in mid-2005 after the increase in imports in early 2005 led to calls for protection. Table 1 summarizes market shares and quota coverage for the top 20 exporters in 2004 and 2005; except for Mexico and Canada, all the biggest exporters had large shares of their trade come in under binding quotas.

Table 2 reports aggregate results for the top 20 exporters. We report quantity, price and quality changes separately for goods subject to a binding quota in 2004 and goods which were not quota constrained, as well as a total for all goods. These aggregate numbers are chain-weighted averages of growth in individual quota groups, where the weights are averages of the 2004 and 2005 shares of each country’s exports. ${ }^{16}$

The results are most dramatic for the largest exporter, China: prices plummeted $38 \%$ for previously constrained goods, with quality falling by $11 \%$. These price drops were associated with a huge increase in the real quantity of imports, with previously constrained categories growing by $450 \%$. By contrast, there was no change in price or

\footnotetext{
${ }^{16}$ The usual approximation that, for small changes, price and quality growth sum to value growth is not accurate here for two reasons. The first is that so many of the changes are very large, and the second is the well-known feature of chain weighting that sums of growth rates will not generally equal growth of the sum.
} 
quality for previously unconstrained goods from China, although the quantity of previously unconstrained goods grew by over $50 \%$. The value of apparel and textile imports from China grew by $44 \%$, and this was mainly in previously constrained goods, which increased their share of China's exports from 19\% in 2004 to 36\% in 2005. This is exactly what trade theory predicts, and the magnitudes are striking.

The South Asian exporters India, Pakistan, and Bangladesh have results similar to China, though smaller in magnitude: big drops in price (especially for Pakistan) and some drop in quality in previously constrained goods, with little price change in unconstrained categories. One surprise is the very fast growth (116\%) in real exports of previously unconstrained goods from India. This may reflect the fact that some quotas with fill rates of less than 90\% were nonetheless binding in the case of India. Hong Kong had similar price drops in all goods, with quality downgrading as expected in previously constrained goods and some quality increase in other goods. Among other previously constrained exporters in the top 10, Korea and Indonesia also had experiences consistent with theory.

The final column of Table 2 makes it clear that there were some clear losers from the end of the MFA. The biggest loser was Mexico, whose real exports fell by $7 \%$ and total export value fell by $6.5 \%$. The other NAFTA exporter, Canada, suffered a similar fate.

Hong Kong, Korea and Taiwan saw their value of exports fall, with Korea and Taiwan actually seeing a drop in real shipments despite being freed from the constraints of the MFA. We conjecture that the decline of these three exporters is due to the increased competition from China: with low-wage China no longer constrained, the relatively high-wage exporters could no longer compete. To state the same point somewhat differently, these three countries were large exporters to the U.S. precisely because of their historically high quota allocations, an advantage that disappeared on January 12005.

The country results reported in Table 2 are illustrated in Figure 1, which reveals the strong negative correlation $(-0.77)$ between price changes and increases in imports.

\subsection{STATISTICAL RESULTS}

The results just summarized are striking, but Table 2 can not address the question of whether the differences between constrained and unconstrained categories are statistically 
significant. To answer this question we estimate a two way fixed effect model. Pooling across countries $c$ and quota groups $g$, we estimate

$$
\ln F_{c g t}=\alpha_{c g}+d_{t}+\beta^{F} c_{c g t}+\gamma^{F} q_{c g t}+\varepsilon_{c g t}
$$

where $\ln F_{c g t}$ is the exact price index (4), $\alpha_{c g}$ is a fixed effect for each country-quota group, $d_{t}$ is a time fixed effect, and $\varepsilon_{c g t}$ is an error term. Our measures of the effects of quotas are also dummy variables: $c_{c g t}$ takes the value 1 if the quota group was binding on December 31, 2004 (defined as fill rate greater than 90\%) and 0 otherwise, and $q_{c g t}$ takes the value 1 if the quota group had a quota re-imposed in 2005 that was binding and 0 otherwise.

Thus $\beta^{F}$ is the average reduced form effect of ending a binding quota on the exact price index, using only within-cg variation over time, and controlling for the average price change in each year. The effect $\beta^{F}$ is identified by difference-in-difference variation: it says how prices in quota constrained categories changed in 2005 as opposed to prices in unconstrained categories. The null hypothesis is that $\beta^{F}<0$.

The coefficient $\gamma^{\mathrm{F}}$ measures the reduced form effect of new quotas in 2005 on prices of the restricted goods in 2005, relative to the baseline, which includes all goods. There were 13 quotas active on Chinese exports in 2005, which can be mapped into 11 binding quotas on categories which were in use pre-2005. Of these 11 binding quotas, 9 were on categories which were also subject to binding quotas in 2004, thus $\beta^{F}+\gamma^{F}$ is the total average effect on price in 2005 for these 9 categories; for the other two, the effect is just $\gamma^{\mathrm{F}}$.

Analogously, we regress the quality indices on the same explanatory variables,

$$
\ln Q_{c g t}=\alpha_{c g}+d_{t}+\beta^{Q} C_{c g t}+\gamma^{Q} q_{c g t}+\varepsilon_{c g t}
$$

Following the logic in the preceding two paragraphs, the hypothesis that quotas cause quality upgrading leads us to expect $\beta^{Q}<0$.

We emphasize that our aim in estimating (7) and (8) is purely statistical: are the differences reported in Table 2, and illustrated in Figure 1, statistically significant? A structural estimate of the effect of quotas on prices is beyond the scope of this paper, as it would require a detailed model of market equilibrium in the global apparel and textile 
industry. To illustrate just one consideration, the United States was not the only big importer to wait until the end of 2004 to eliminate most MFA quotas: the European Union did the same. Thus the price effects found in our estimates may be related to developments in the European market as well, although any such effects would tend to dampen the price falls on exports to the US market ${ }^{17}$. The reduced form effects that we consistently estimate with (7) and (8) are facts that any model of this episode will have to match, but they do not by themselves dictate the form of such a model.

We estimate equations (7) and (8) for all countries and quota groups, and separately for China and all other countries. The results are reported in Table 3. When all countries are pooled together, the effect of a binding quota in 2004 is to lower prices in 2005 by $18 \%$, a result which is highly statistically significant. The quality downgrading effect is smaller, at $-5 \%$, and statistically significant. More illuminating results are seen when China is separated from other countries. The binding quota effect is $-32 \%$ for China, and $-10 \%$ for other countries, both of which are statistically significant. Quality downgrading is large and significant for China $(-7 \%, t=-2.7)$, and much smaller for other countries(-4\%, $t=-2.8)$.

Curiously, $\gamma^{\mathrm{F}}$ is large (-21\% for prices, $-13 \%$ for quality), significant and negative for China. We would have expected $\gamma^{\mathrm{F}}$ to be positive because theory predicts that reimposing quotas in 2005 should raise the price and quality of these goods. But considering that reinstating the quotas in 2005 was a protective measure against the onslaught of cheap Chinese goods, it is not hard to interpret the negative $\gamma^{\mathrm{F}}$ : the U.S. saw the prices of these quota groups dropping and reinstated quotas to keep them from dropping even more. Thus, $\gamma^{\mathrm{F}}$ is picking up the initial price and quality fall resulting from the end of the MFA. This interpretation is supported by an analysis of monthly data on imports from China, which is summarized in Figure 2. To construct Figure 2, we calculated yearly growth rates of values and unit values for each month in 2005 (that is, we calculated growth from January 2004 to January 2005, February 2004 to February 2005 , etc). These yearly growth rates control for the very pronounced seasonality in

\footnotetext{
${ }^{17}$ To see this, assume that marginal costs in supplier countries are flat or upward sloping in quantity supplied. If they are flat then there is no effect on sales to the US when sales to the EU increase, while if they are upward sloping then an increase in supply to the EU will raise costs (and hence limit post-quota price declines) to the US.
} 
monthly trade data. In the Figure, we divide trade into four categories depending on whether quotas were binding in 2004, 2005, both years, or neither year. Panel (a) shows that the highest value growth rates in the first half of the year were in those categories that had binding quotas in 2004 which were then subject to new quotas by mid-2005. Not surprisingly, growth comes to a halt in these categories after the new quotas are imposed. Panel (b) confirms our interpretation of our negative estimate of $\gamma^{\mathrm{F}}$ : the goods which had quotas re-imposed had faster unit value drops throughout the year than goods which did not have quotas re-imposed.

The estimated time fixed effects are of interest because they tell us what prices were doing on average in each year. As can be seen from Table 3, the answer is "not much”: prices were rising about 5 percent per year in between 2003 and 2005, and quality was essentially unchanging.

The statistical results can be visualized quite effectively using smoothed histograms, or kernel densities. Figure 3 plots the distribution of log price changes between 2004 and 2005 for all quota groups except the 11 quota groups that had quotas re-imposed in 2005 (we leave out these 11 because doing so yields a clearer picture of the MFA's effect on prices). Quota groups which were constrained in 2004 are plotted separately from unconstrained quota groups in Figures 3 and 4, and China is separated from other countries. As one would expect from the regression results, the distribution for constrained quota groups is centered to the left of the unconstrained quota group's distribution: constrained quota groups tend to have greater price falls in 2005 than unconstrained quota groups. The effect is much larger for China than for other countries.

Figure 4 has the same structure as Figure 3, but plots log quality changes rather than price changes. There is clearly evidence of systematic quality downgrading in formerly constrained quota groups from China, but much weaker evidence of the same phenomenon outside China.

As a final check on our regression results, we estimate equations (7) and (8) separately for each country, with results reported in Table 5 (time fixed effects are not reported to save space). Because of small sample sizes at the country level, many results are not statistically significant, but the message is the same as from Table 3: consistently 
negative and mainly statistically significant point estimates for the price effect of quota removal, with smaller and usually statistically insignificant effects on quality.

\subsection{WELFARE EFFECTS}

To calculate the consumer welfare costs of the MFA, we compute the approximations to equivalent variation and compensating variation as defined in (1), taking 2004 as the prereform period and 2005 as the post-reform period. For welfare comparisons, the correct price to use in each year is the price received by foreign residents, which means that the price should not include tariff revenue. The correct treatment of transport charges depends on who pays them: if foreigners pay them then the price relevant to U.S. residents does not include transport charges, but if U.S. residents pay the transport charges then they should be included in the price for welfare calculations. We have accurate data on transport costs but not on their incidence, so we do the calculations using the two extreme assumptions that they are paid completely by foreigners (the f.o.b. or “free on board” price) and completely by U.S. residents (the c.i.f or “cost, insurance, and freight” price). We report results for the simple average of these polar assumptions on transport cost incidence in Table 5. The Table reports total changes in welfare, and also reports subtotals by 2004 quota coverage and by exporter.

The interpretation of the numbers in Table 5 is straightforward. The approximate equivalent variation between 2004 and 2005, or the amount US consumers in 2005 would need to be paid to go back to the pre-reform period, was $\$ 9.77$ billion. The compensating variation, or the amount US consumers would have been willing to pay to be rid of the MFA in 2004, is $-\$ 336$ million.

The fact that $C V$ is slightly negative is a surprise. Numerically, the explanation is simple: by using pre-reform quantity weights, our approximation to $C V$ gives very little weight to the products whose prices fell the most. Some prices rose between 2004 and 2005, and these products had substantial market share in 2004. For example, prices from Mexico, the second biggest supplier, rose 4\%, while prices from Korea rose 7\% (see Table 2). These price increases get a negative weight in the $C V$ calculation, and roughly balance out the price falls from previously quota constrained goods. By contrast, our approximation to $E V$ reflects the changes in market share in 2005, where falling prices 
led to big expansions. The measure $W$ uses the simple average of pre and post-reform quantities as weights, and delivers a welfare gain of $\$ 4.72$ billion.

Unsurprisingly, almost $90 \%$ of the welfare gain came from goods which were previously constrained, although falling prices of previously unconstrained goods were also worth more than $\$ 1.2$ billion in $E V$ (second and third rows of Table 5). When looking at subtotals by exporter, it is striking that the overwhelming majority of the welfare gain is due to China, which accounted for $\$ 8.1$ billion or $83 \%$ of the total $E V$. The second largest positive contribution came from Pakistan, at \$462 million. Other large previously constrained exporters (India, Hong Kong, Indonesia, and Bangladesh) each accounted for around \$250 million in welfare improvement. A few countries had negative welfare contributions, most notably Mexico, Italy, and Turkey. These exporters lost their preferential access to the U.S. market when the MFA expired, and their prices rose, thus leading to a negative welfare effect for U.S. consumers.

How big are these numbers? There were 111 million households in the U.S. in 2005, and the median household spent about $\$ 1,400$ on apparel ${ }^{18}$. Our calculation of $E V$ implies an annual cost of $\$ 88$ per household (6.3\% of the median apparel budget).

The beneficiaries of the MFA included holders of quota rights, and the U.S. workers and firms who benefited from protection. There were 737,000 U.S. workers in the apparel and textile sectors in 2004, with an average annual salary of $\$ 31,500^{19}$. We can not estimate what employment and earnings in these sectors would have been in the absence of the MFA, but it seems likely that this import competing sector would have been badly hit. What we can do is calculate the consumer cost per job of providing MFA protection. Dividing our estimate of equivalent variation by employment gives a consumer cost of $\$ 13,260$ per job protected, or $42 \%$ of average wages in the industry.

\footnotetext{
${ }^{18}$ The number of households comes from the Census Bureau's 2005 American Community Survey. Median household expenditure on apparel is taken from the Bureau of Labor Statistics' 2004 Consumer Expenditure Survey, which reports (Table 1) that the middle quintile of consumer units (which are similar to households) spent $\$ 1,477$ on “Apparel and services”, a category that includes dry cleaning, tailoring, etc, so we round down to $\$ 1,400$.

${ }^{19}$ Source is the Bureau of Economic Analysis. The industry is defined as NAICS 1997 codes 313/314/315/316, which is Textile Mills, Textile Product Mills, Apparel Manufacturing, and Leather and Allied Product Manufacturing.
} 


\section{CONCLUSION}

The end of the MFA in 2004 provided a unique opportunity to robustly test some simple

predictions of the theory of trade policy: quotas raise prices and lead to inefficient quality upgrading. We showed that this is exactly what happened: in quota constrained categories, prices fell 38\% from China and quality fell 11\%. The price effects were also substantial for non-Chinese exporters, with little evidence of quality downgrading.

We are also able to calculate the consumer welfare cost of the MFA. Focusing on the ex post equivalent variation measure of welfare, we find a gain of \$9.8 billion, mainly due to lower prices on imports from China. This gain amounts to an annual benefit per U.S. household of about $\$ 90$, which is more than $6 \%$ of the median household budget. We can also compare the welfare gain to the size of the domestic employment in the apparel and textile sector which was protected by the MFA. We find that the equivalent variation per job protected was more than $\$ 13,000$ per job protected, which is over $40 \%$ of the average salary in the sector.

Despite the flood of cheap Chinese imports in 2005, most other textile and apparel exporters did not suffer from the Chinese market share increase. The reason is that many other big exporters (especially India, Pakistan, Bangladesh, and Indonesia) were able to increase their sales to the U.S. market when their quotas were removed,. The biggest exceptions were countries that previously had privileged access to the U.S. market (including Mexico, Canada, Honduras and El Salvador), who saw export revenues drop. Relatively developed exporters such as Hong Kong, Taiwan, and Korea also suffered export losses despite having their quotas removed, an outcome which probably reflects the fact that these countries could not compete with low-wage exporters in the absence of their historically high quota allocations. 


\section{REFERENCES}

Anderson, James E., 1988, The Relative Inefficiency of Quotas, Cambridge, MA: MIT Press.

Brambilla, Irene, Amit Khandelwal, and Peter Schott, 2007, "China's Experience Under the Multifiber Arrangement (MFA) and the Agreement on Textiles and Clothing (ATC)", NBER Working Paper No. 13346 (August).

Broda, Christian, and David Weinstein, 2006, “Globalization and the Gains from Variety”, Quarterly Journal of Economics 121(2): 541-585 (May).

Boorstein, Randi, and Robert C. Feenstra, 1991, "Quality Upgrading and Its Welfare Cost in U.S. Steel Imports, 1969-74”, in Elhanan Helpman and Assaf Razin, Editors, International Trade and Trade Policy, Cambridge, MA: MIT Press.

Deaton, Angus, and John Muellbauer, 1980, Economics and Consumer Behavior, Cambridge, UK: Cambridge University Press.

Evans, Carolyn L., and James Harrigan, 2005, “Tight Clothing: How the MFA Affects Asian Apparel Exports”, East Asian Seminar on Economics 14: International Trade, Chapter 11, 2005, Takatoshi Ito and Andrew Rose, Eds., University of Chicago Press.

Falvey, Rodney E., 1979, “The composition of trade within import-restricted categories”, Journal of Political Economy 87 (5): 1105-1114.

Feenstra, Robert C., 1988, “Quality Change under Trade Restraints in Japanese Autos”, Quarterly Journal of Economics 103:131-146.

Feenstra, Robert C., 1995, "Estimating the effects of trade policy”, Handbook of International Economics, Volume 3, Gene M. Grossman and Kenneth Rogoff, Editors, Amsterdam: North Holland.

Feenstra, Robert C., 2004, Advanced International Trade. Princeton: Princeton University Press.

Finger, J. Michael, and Anne Harrison. Import Protection for U.S. Textiles and Apparel: Viewed from the Domestic Perspective. The political economy of trade protection. (4349) National Bureau of Economic Research Project Report Series: University of Chicago Press, 1996.

Hummels, David, and Alexandre Skiba, 2004, "Shipping the Good Apples Out? An Empirical Confirmation of the Alchian-Allen Conjecture”, Journal of Political Economy 112(6): 1384-1402 (December). 
Kee, Hiau Looi, Marcelo Olarreaga, and Alessandro Nicita, 2006, "Estimating trade restrictiveness indices”, World Bank Policy Research Working Paper 3840.

Krishna, Kala M., 1989, “Trade restrictions as facilitating practices”, Journal of International Economics 26: 251-270.

Krishna, Kala M., and Ling Hui Tan. Rags and Riches: Implementing Apparel Quotas under the Multi-Fibre Arrangement. Ann Arbor: University of Michigan Press, 1998. Laird, Sam, and Alexander Yeats, 1990, Quantitative Methods for Trade barrier Analysis, New York: NYU Press.

Office of Textiles and Apparel (OTEXA). Tariff (Duty) Rate Reductions. May 1995 $<$ http://otexa.ita.doc.gov/duty.htm> (30 October 2003).

--- Integration http://otexa.ita.doc.gov/integ.htm (30 October 2003).

--- United States Final Integration by Phase http://otexa.ita.doc.gov/fedreg /FINAL_List.pdf (30 October 2003).

Pregelj, Vladimir N. IB95050: Caribbean Basin Interim Trade Program: CBI/NAFTA Parity. Congressional Research Service. Foreign Affairs, Defense and Trade Division, CRS Issue Brief for Congress, 21 November 2000.

Rodriguez, Carlos Alfredo, 1979, “The quality of imports and the differential welfare effects of tariffs, quotas, and quality controls as protective devices”, Canadian Journal of Economics 12 (3): 439-449.

Romalis, John, 2005, “NAFTA's and CUSFTA's Impact on International Trade”, NBER WP no. 11059.

Scotchmer, Suzanne, 1989, “Equivalent variation with uncertain prices”, Economics Letters 30 (2): 117-118.

Shelburne, Robert C. and Elaine L. Chao. Trade and Employment Effects of the Andean Trade Preference Act. Bureau of International Labor Affairs. Economic Discussion Paper No. 60., 2002.

Trefler, Daniel, 1993, “Trade Liberalization and the Theory of Endogenous Protection: An Econometric Study of U.S. Import Policy.” Journal of Political Economy 101 (February): 138-160.

Trefler, Daniel, 2004, "The Long and Short of the Canada-U.S. Free Trade Agreement”, American Economic Review 94 (4): 870-895.

United States International Trade Commission (USITC) The Economic Effects of Significant U.S. Import Restraints. Third Update 2002, June 2002.

World Trade Organization (WTO-CFG), Council for Trade in Goods, G/L/224, 19 February 1998, (98-0574), Major Review of the Implementation of the Agreement on 
Textiles and Clothing in the First Stage of the Integration Process. Adopted by the Council on 16 February 1998.

World Trade Organization (WTO) Textiles: Agreement, Textiles Monitoring Body (TMB), The Agreement on Textiles and Clothing, <http://www.wto.org/english/tratop_e/texti_e /texintro_e.htm> (30 October 2003). 
Table 1 - U.S. Apparel and Textile imports, top 20 exporters

\begin{tabular}{|l|c|c|c|}
\hline \multirow{2}{*}{ China } & quota & \multicolumn{2}{|c|}{ market share } \\
\cline { 3 - 4 } coverage & 2004 & 2004 & 2005 \\
\cline { 2 - 4 } Mexico & 18.0 & 20.7 & 27.8 \\
India & 0 & 9.7 & 8.4 \\
Canada & 36.0 & 4.5 & 5.3 \\
Hong Kong & 0 & 4.1 & 3.6 \\
Korea & 50.4 & 3.6 & 2.9 \\
Honduras & 27.7 & 3.4 & 2.4 \\
Vietnam & 0 & 3.1 & 2.8 \\
Indonesia & 29.1 & 3.1 & 3.0 \\
Pakistan & 64.2 & 2.9 & 3.2 \\
Italy & 42.3 & 2.9 & 3.1 \\
Taiwan & 0 & 2.8 & 2.5 \\
Thailand & 18.5 & 2.6 & 2.0 \\
Bangladesh & 18.0 & 2.6 & 2.3 \\
Philippines & 34.9 & 2.3 & 2.6 \\
Turkey & 31.6 & 2.2 & 2.0 \\
El Salvador & 2.3 & 2.0 & 1.7 \\
Sri Lanka & 0 & 2.0 & 1.7 \\
Guatemala & 28.0 & 1.8 & 1.8 \\
Cambodia & 0.3 & 1.7 & 1.5 \\
Other & 44.4 & 1.6 & 1.8 \\
Total & & 20.5 & 17.5 \\
\hline & 16.7 & 100.0 & 100.0 \\
\hline
\end{tabular}


Table 2 - Quantity, price, quality and value change 2004-2005, U.S. Apparel and textile imports, top 20 exporters

\begin{tabular}{|c|c|c|c|c|c|c|c|c|c|c|}
\hline & total & $\begin{array}{c}\text { quantity } \\
\text { not } \\
\text { bound }\end{array}$ & $\begin{array}{c}\text { bound } \\
2004\end{array}$ & total & $\begin{array}{c}\text { price } \\
\text { not } \\
\text { bound }\end{array}$ & $\begin{array}{c}\text { bound } \\
2004\end{array}$ & total & $\begin{array}{c}\text { quality } \\
\text { not } \\
\text { bound }\end{array}$ & $\begin{array}{c}\text { bound } \\
2004\end{array}$ & $\begin{array}{l}\text { value } \\
\text { total }\end{array}$ \\
\hline China & 155.9 & 51.8 & 449.6 & -10.2 & -1.0 & -37.8 & -3.0 & -0.3 & -11.2 & 44.7 \\
\hline Mexico & -7.0 & -7.0 & & 4.0 & 4.0 & & 0.6 & 0.6 & & -6.5 \\
\hline India & 124.5 & 166.3 & 54.1 & -1.9 & 2.3 & -9.2 & -1.2 & -0.4 & -2.7 & 27.6 \\
\hline Canada & -2.0 & -2.0 & & 1.7 & 1.7 & & -0.9 & -0.9 & & -5.3 \\
\hline Hong Kong & 21.8 & 27.5 & 16.9 & -2.2 & -1.6 & -2.8 & 0.6 & 5.5 & -4.0 & -13.7 \\
\hline Korea & -11.3 & -14.0 & -3.7 & 3.9 & 7.1 & -4.9 & -2.3 & -1.7 & -3.8 & -21.9 \\
\hline Honduras & 1.8 & 1.8 & & -1.8 & -1.8 & & -2.3 & -2.3 & & -1.9 \\
\hline Vietnam & 11.0 & 18.5 & -9.4 & 3.0 & 2.2 & 5.0 & 0.4 & 0.6 & 0.0 & 5.9 \\
\hline Indonesia & 41.7 & 27.8 & 49.3 & -5.0 & 1.7 & -8.4 & -1.7 & 0.4 & -2.7 & 18.0 \\
\hline Pakistan & 54.7 & -0.1 & 113.3 & -8.6 & -0.4 & -17.6 & 0.4 & 0.5 & 0.2 & 14.4 \\
\hline Italy & -11.5 & -11.5 & & 12.4 & 12.4 & & 0.3 & 0.3 & & -4.0 \\
\hline Taiwan & -11.7 & -11.1 & -14.6 & 3.5 & 3.4 & 4.1 & 0.4 & 0.7 & -0.9 & -19.3 \\
\hline Thailand & 6.9 & -1.4 & 39.6 & 0.1 & 1.8 & -6.5 & -3.1 & -3.3 & -2.3 & -3.1 \\
\hline Bangladesh & 40.0 & 25.0 & 64.6 & -6.6 & -4.9 & -9.2 & -1.6 & -2.1 & -0.7 & 18.8 \\
\hline Philippines & 19.2 & 8.0 & 41.6 & -3.4 & -0.2 & -9.7 & -2.7 & -2.2 & -3.7 & -1.1 \\
\hline Turkey & -7.6 & -9.6 & 53.7 & 8.4 & 8.5 & 6.1 & 4.6 & 5.3 & -16.6 & -8.3 \\
\hline El Salvador & 0.8 & 0.8 & & -2.7 & -2.7 & & -4.1 & -4.1 & & -6.3 \\
\hline Sri Lanka & 19.2 & 9.6 & 41.5 & -3.1 & -0.6 & -8.4 & -2.4 & -2.6 & -2.1 & 5.5 \\
\hline Guatemala & 2.3 & 0.8 & 202.8 & -3.9 & -4.0 & 0.2 & -0.4 & -0.3 & -7.5 & -6.1 \\
\hline Cambodia & 41.2 & 8.9 & 75.5 & -7.0 & 1.7 & -16.1 & -2.6 & 0.0 & -5.3 & 19.9 \\
\hline
\end{tabular}

Notes to Table 2: All entries are percent changes between 2004 and 2005. Columns headed "bound 2004” aggregate products subject to a binding quota in 2004, with all other products aggregated in the "not bound" columns. 
Figure 1a - Price changes 2004-2005, top 20 exporters, ordered by total price change

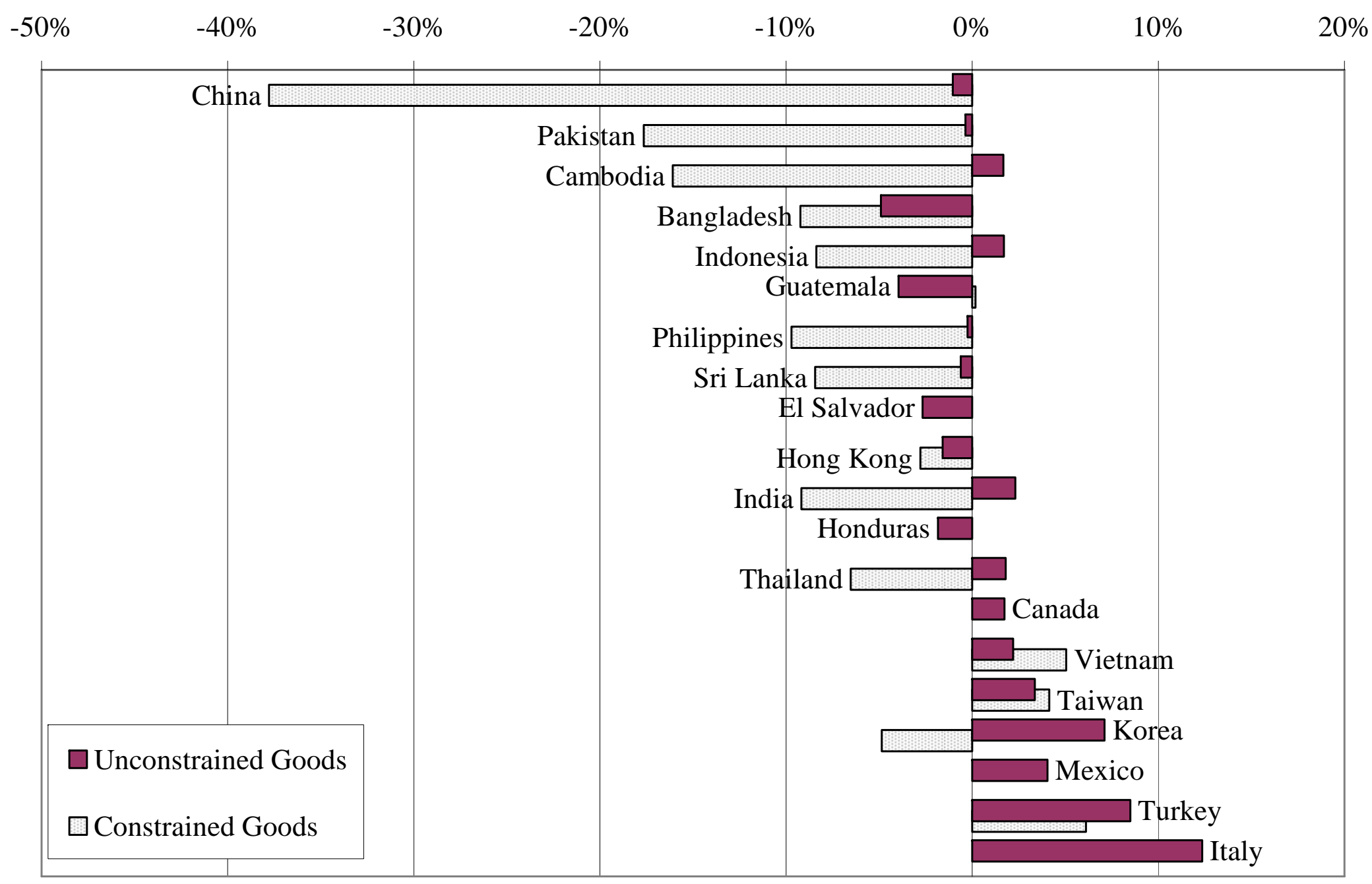


Figure 1b - Quantity changes 2004-2005, top 20 exporters, ordered by total price change

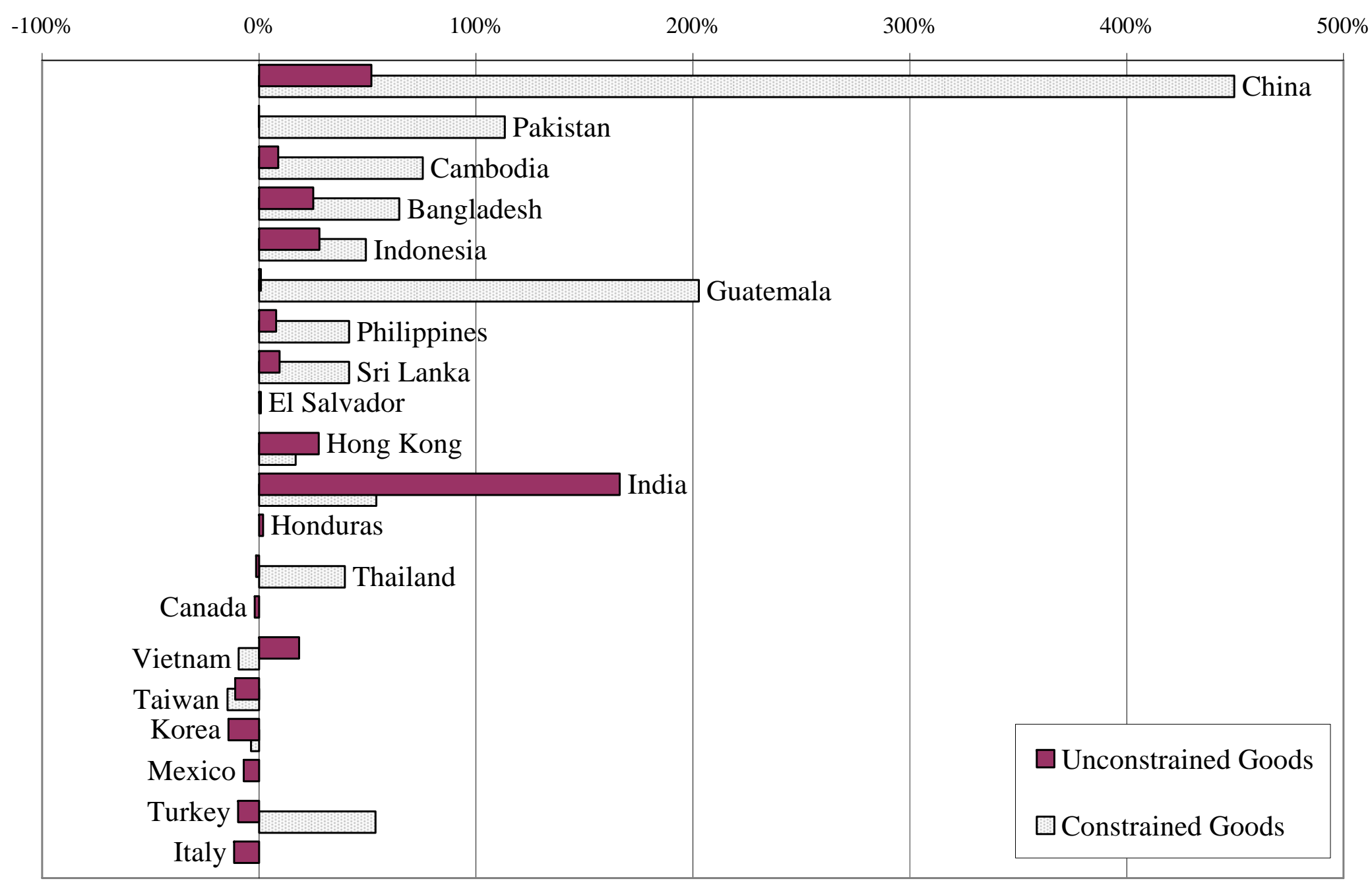


Table 3 - Regression estimates of effects of MFA elimination on price, quality

\begin{tabular}{|c|c|c|c|c|}
\hline & & $\begin{array}{c}\text { All } \\
\text { Countries }\end{array}$ & China & $\begin{array}{l}\text { Non- } \\
\text { China }\end{array}$ \\
\hline \multirow{10}{*}{ Price } & \multirow{2}{*}{2003} & 0.02 & -0.03 & 0.03 \\
\hline & & 3.43 & -1.32 & 3.55 \\
\hline & \multirow{2}{*}{2004} & 0.07 & 0.03 & 0.07 \\
\hline & & 8.63 & 1.49 & 8.55 \\
\hline & \multirow{2}{*}{2005} & 0.06 & -0.06 & 0.06 \\
\hline & & 8.06 & -2.60 & 8.23 \\
\hline & \multirow{2}{*}{$\beta^{F}$} & -0.18 & -0.32 & -0.10 \\
\hline & & -8.75 & -7.06 & -5.85 \\
\hline & \multirow{2}{*}{$\gamma^{F}$} & -0.41 & -0.21 & \\
\hline & & -6.39 & -2.79 & \\
\hline \multirow{10}{*}{ Quality } & \multirow{2}{*}{2003} & -0.01 & -0.00 & -0.01 \\
\hline & & -1.59 & -0.24 & -1.57 \\
\hline & \multirow{2}{*}{2004} & -0.05 & -0.00 & -0.05 \\
\hline & & -7.59 & -0.13 & -7.59 \\
\hline & \multirow{2}{*}{2005} & -0.01 & -0.02 & -0.01 \\
\hline & & -0.87 & -1.19 & -0.84 \\
\hline & \multirow[t]{2}{*}{$\beta^{F}$} & -0.05 & -0.07 & -0.04 \\
\hline & & -4.39 & -2.67 & -2.84 \\
\hline & \multirow{2}{*}{$\gamma^{\mathrm{F}}$} & -0.17 & -0.13 & \\
\hline & & -2.59 & -1.83 & \\
\hline \multirow{2}{*}{$\begin{array}{c}\text { Sample } \\
\text { size }\end{array}$} & \multirow{2}{*}{$\begin{array}{l}\text { total } \\
\text { Quota } \\
\text { groups }\end{array}$} & 26,540 & 637 & 25,903 \\
\hline & & 8,526 & 160 & 8366 \\
\hline
\end{tabular}

Notes to Table 3: Each column presents results from two regressions, with log price and log quality respectively regressed on the same set of indicator variables. Robust $t$-statistics in italics below OLS slope estimates. 
Table 4 - Regression estimates of effects of MFA elimination on price, quality, top 20 exporters

\begin{tabular}{|c|c|c|c|c|c|c|c|c|c|c|}
\hline \multirow{6}{*}{$\begin{array}{l}\text { China } \\
\text { Mexico } \\
\text { India } \\
\text { Canada } \\
\text { Hong Kong }\end{array}$} & \multicolumn{4}{|c|}{ Price } & \multicolumn{4}{|c|}{ Quality } & \multicolumn{2}{|c|}{ sample size } \\
\hline & -0.32 & -7.1 & -0.21 & -2.8 & -0.07 & -2.7 & -0.13 & -1.8 & 637 & 160 \\
\hline & & & & & & & & & 522 & 145 \\
\hline & -0.13 & -2.1 & & & -0.08 & -1.9 & & & 520 & 142 \\
\hline & & & & & & & & & 641 & 164 \\
\hline & -0.10 & -1.4 & & & 0.01 & 0.2 & & & 462 & 123 \\
\hline Korea & -0.19 & -3.8 & & & 0.01 & 0.3 & & & 502 & 140 \\
\hline Honduras & & & & & & & & & 199 & 60 \\
\hline Vietnam & -0.04 & -0.7 & & & 0.02 & 0.6 & & & 385 & 120 \\
\hline Indonesia & -0.09 & -2.0 & & & -0.05 & -1.3 & & & 428 & 120 \\
\hline Pakistan & -0.17 & -1.8 & & & -0.03 & -0.6 & & & 339 & 99 \\
\hline Italy & & & & & & & & & 671 & 168 \\
\hline Taiwan & 0.05 & 0.4 & & & 0.03 & 0.6 & & & 433 & 126 \\
\hline Thailand & -0.04 & -0.7 & & & -0.06 & -0.9 & & & 489 & 135 \\
\hline Bangladesh & -0.08 & -1.2 & & & 0.05 & 1.0 & & & 280 & 83 \\
\hline Philippines & -0.17 & -2.5 & & & -0.01 & -0.2 & & & 380 & 114 \\
\hline Turkey & 0.04 & 0.5 & & & -0.24 & -1.6 & & & 455 & 135 \\
\hline El Salvador & & & & & & & & & 269 & 78 \\
\hline Sri Lanka & -0.03 & -0.4 & & & 0.01 & 0.2 & & & 254 & 78 \\
\hline Guatemala & -0.05 & -0.9 & & & -0.10 & -3.3 & & & 293 & 91 \\
\hline Cambodia & -0.26 & -5.0 & & & -0.12 & -1.8 & & & 207 & 70 \\
\hline
\end{tabular}

Notes to Table 4: Each row presents results from two regressions, with year fixed effects suppressed. Robust $t$ statistics in italics to the right of OLS slope estimates. 
Figure 2 - Monthly changes, Chinese exports 2005

(a) Values, growth from same month in 2004

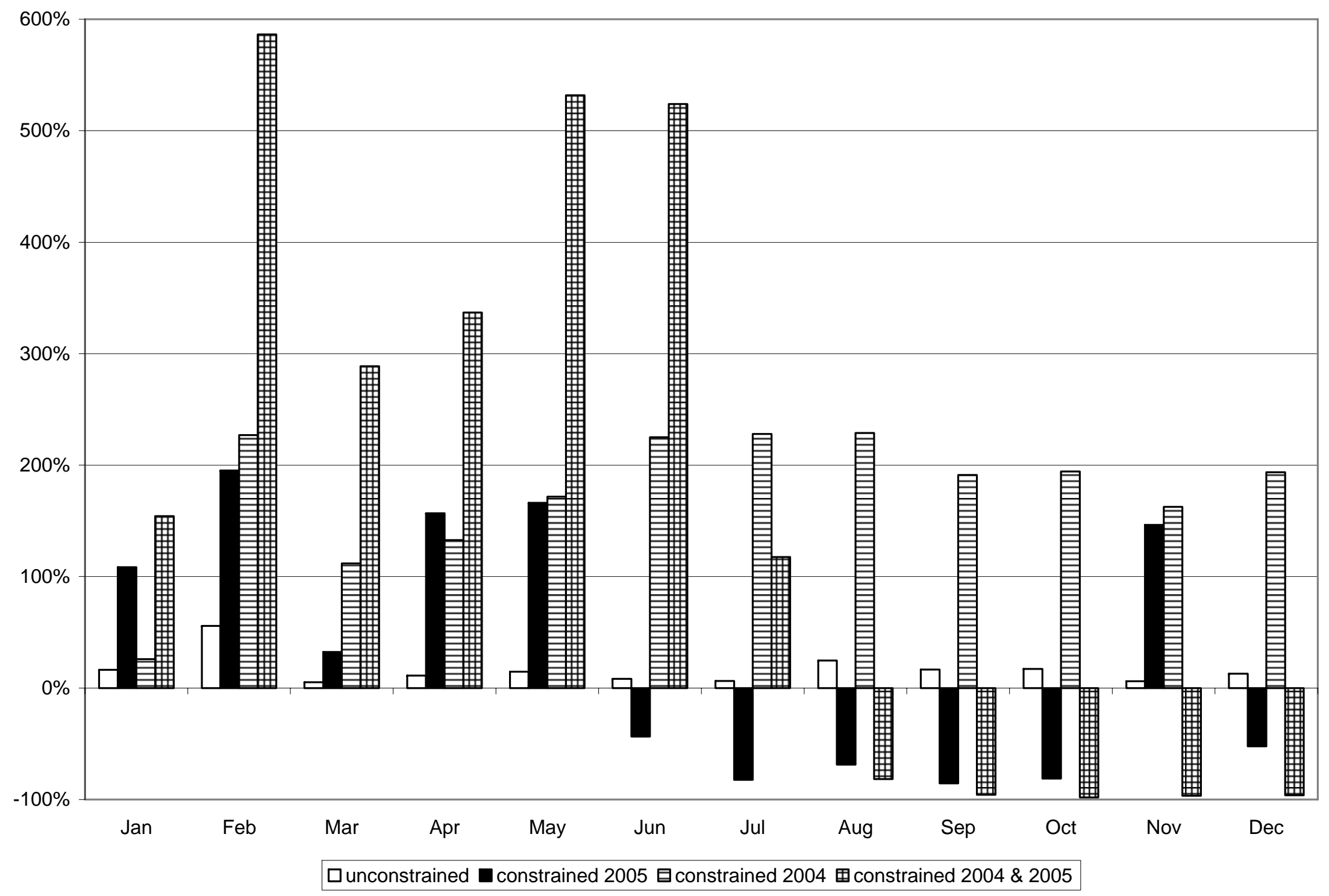


Figure 2, continued - Monthly changes, Chinese exports 2005

(b) Unit values, growth from same month in 2004

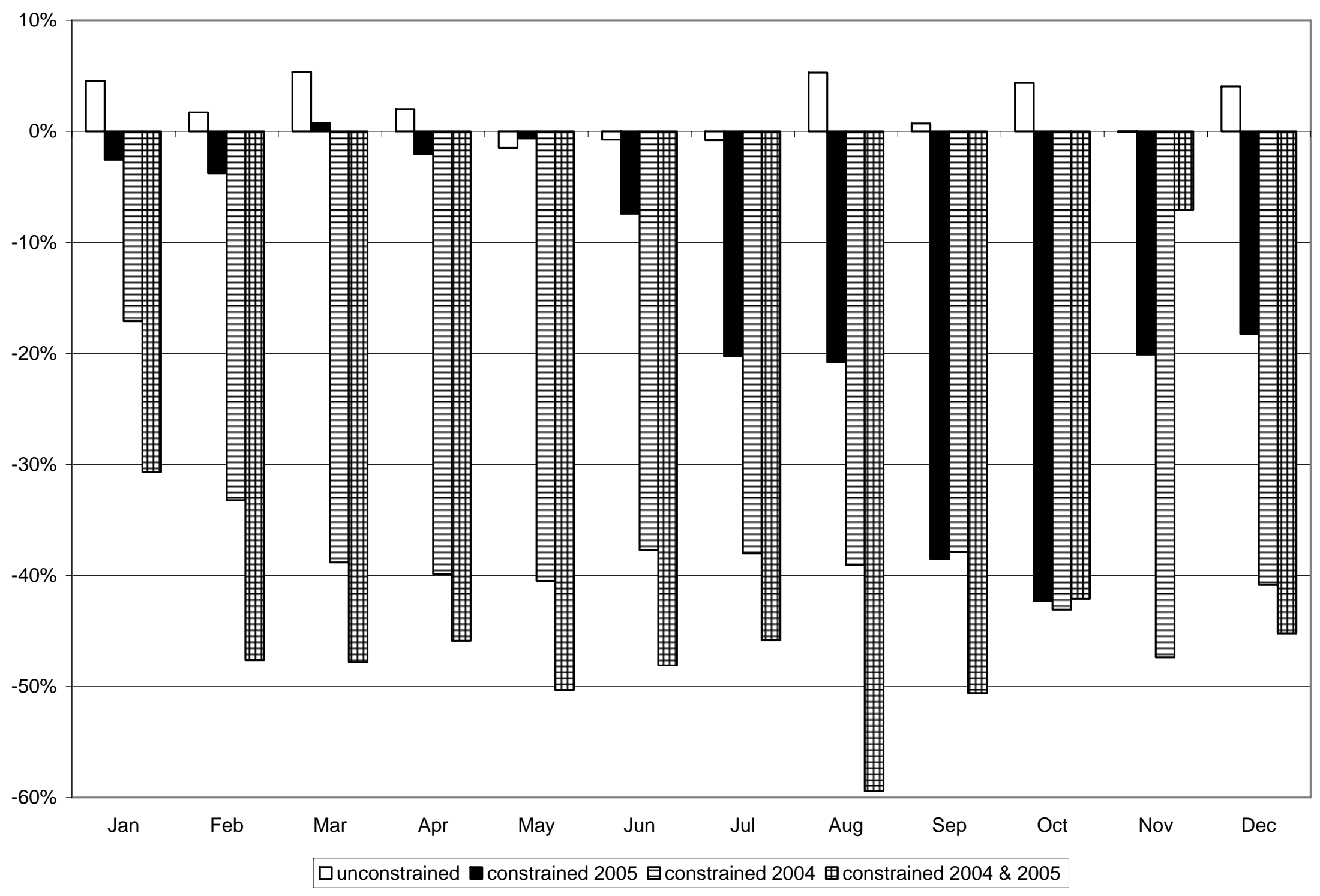


Figure 3 - Distribution of price changes, 2004-2005

(a) China

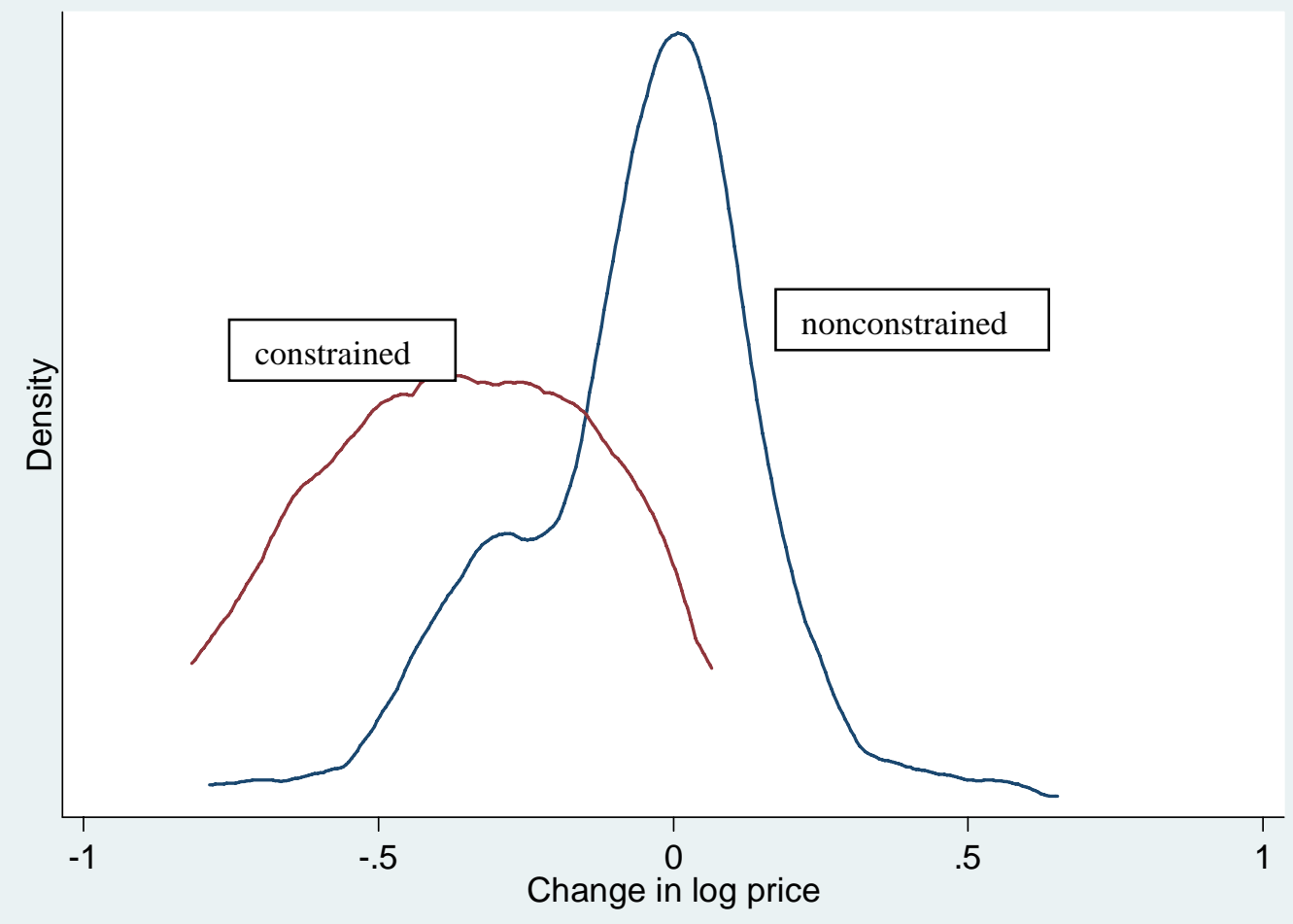

(b) all other countries

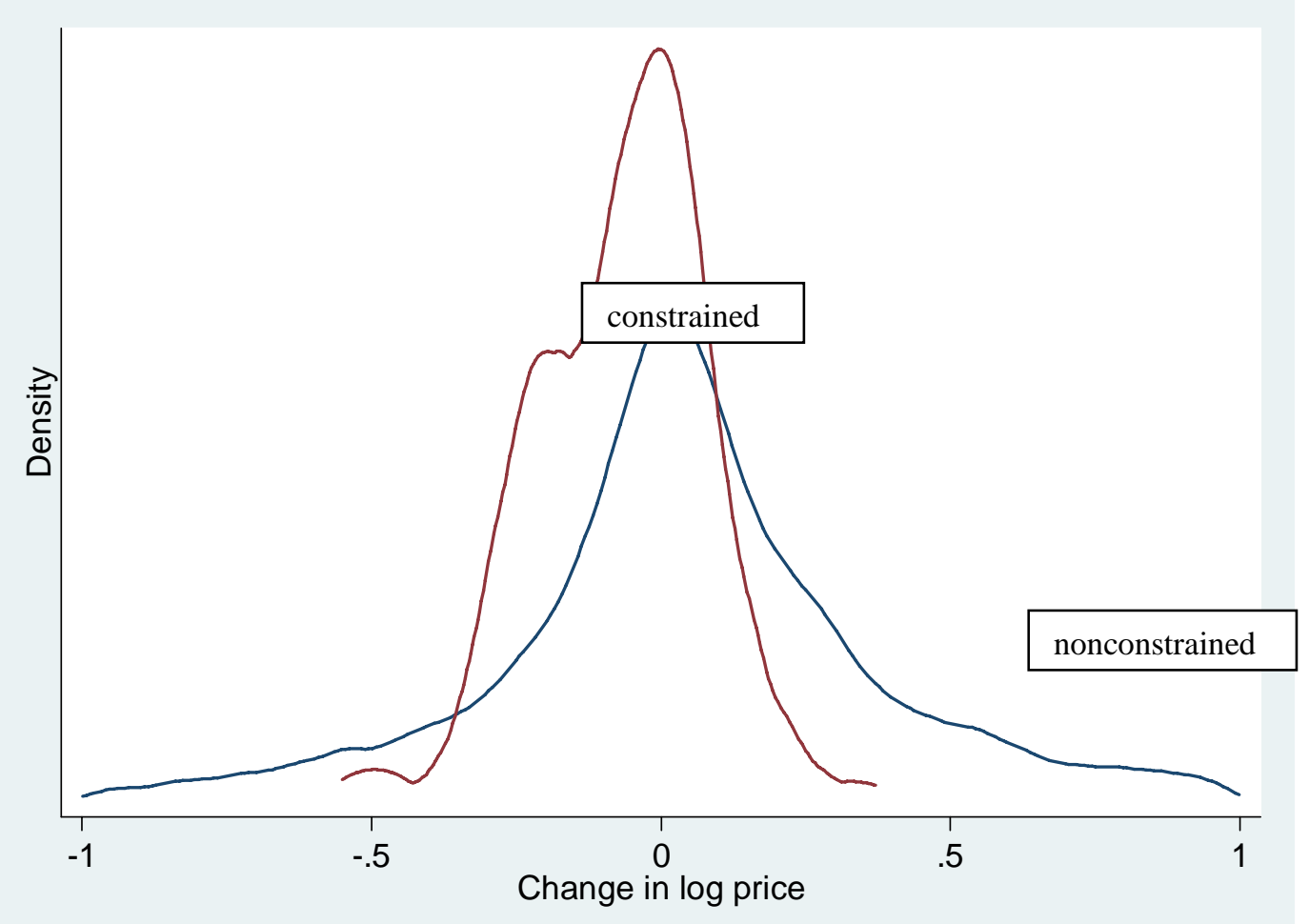


(a) China

Figure 4 - Distribution of quality changes, 2004-2005

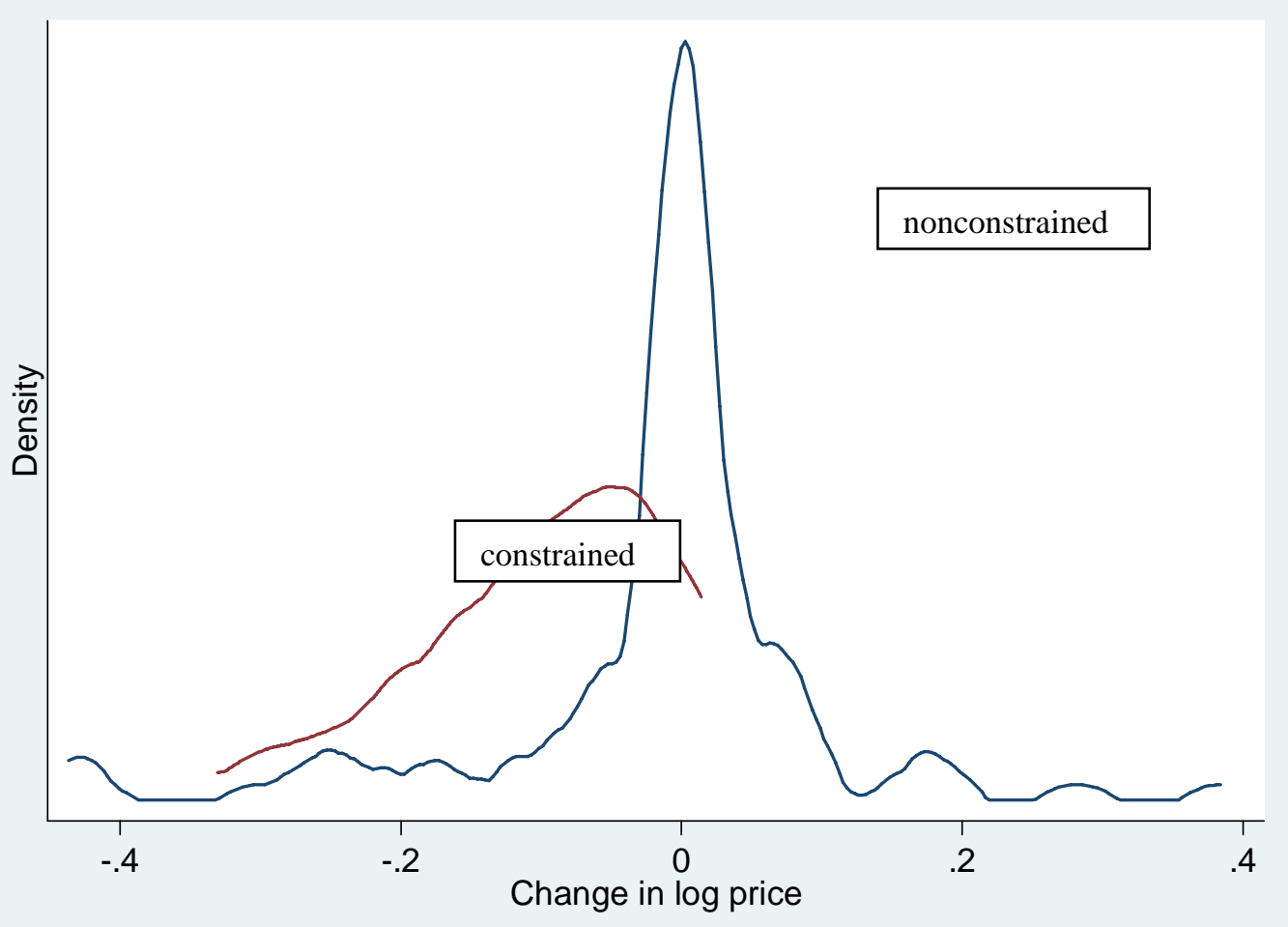

(b) all other countries

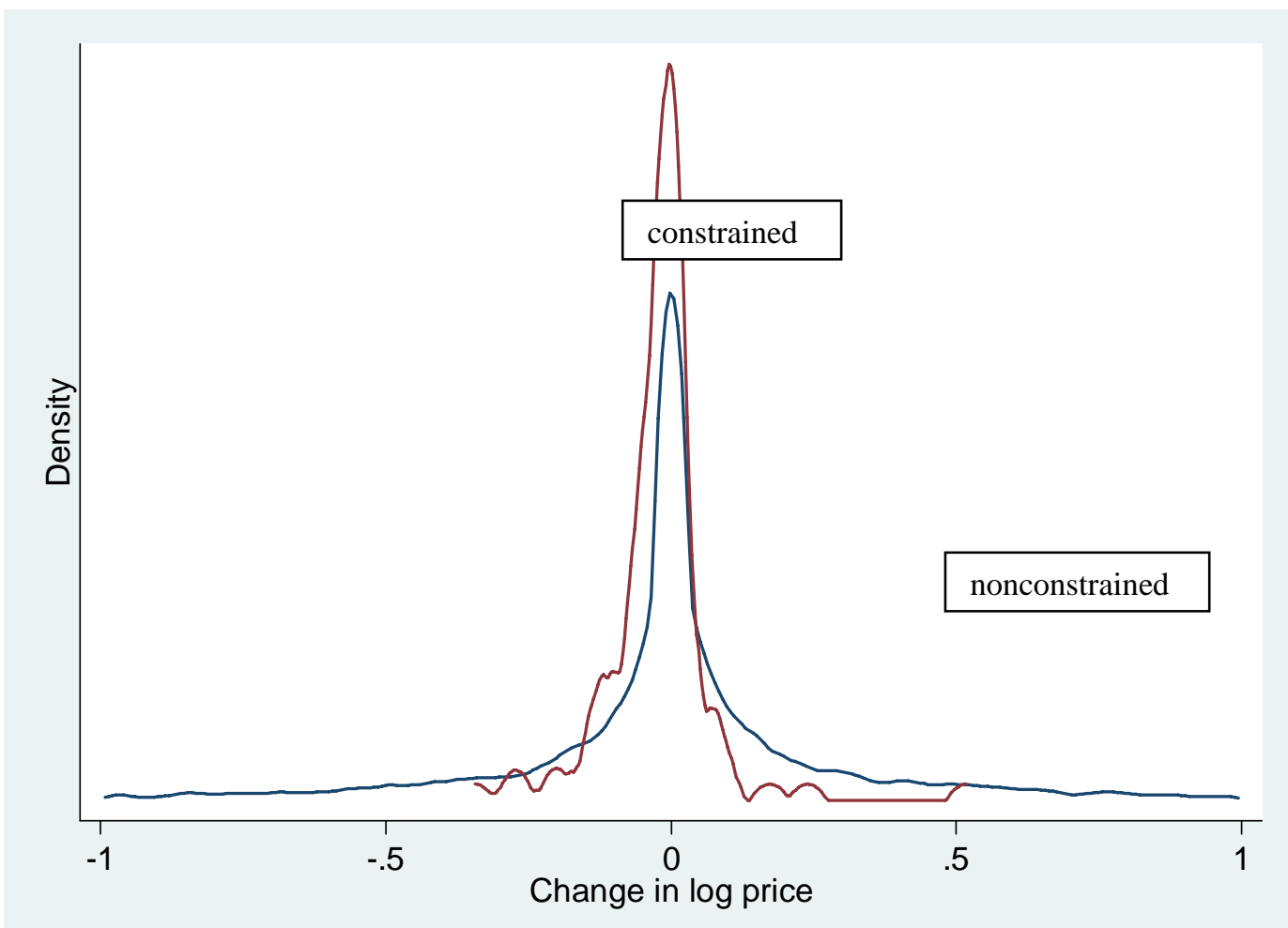


Table 5 - Consumer welfare consequences of the end of the MFA

\begin{tabular}{|c|c|c|c|}
\hline & $E V$ & $W$ & $C V$ \\
\hline total & 9,773 & 4,718 & -336 \\
\hline \multicolumn{4}{|c|}{ by binding quota status in 2004 : } \\
\hline unconstrained & 1,215 & -535 & $-2,286$ \\
\hline constrained & 8,558 & 5,254 & 1,950 \\
\hline \multicolumn{4}{|l|}{ by exporter: } \\
\hline China & 8,131 & 4,660 & 1,189 \\
\hline Mexico & -232 & -267 & -302 \\
\hline India & 248 & 152 & 57 \\
\hline Canada & 40 & -15 & -71 \\
\hline Hong Kong & 234 & 118 & 3 \\
\hline Korea & -13 & -91 & -169 \\
\hline Honduras & 59 & 59 & 58 \\
\hline Vietnam & -76 & -81 & -87 \\
\hline Indonesia & 261 & 191 & 121 \\
\hline Pakistan & 462 & 328 & 194 \\
\hline Italy & -243 & -287 & -331 \\
\hline Taiwan & -21 & -62 & -102 \\
\hline Thailand & 47 & 17 & -13 \\
\hline Bangladesh & 264 & 194 & 124 \\
\hline Philippines & 166 & 110 & 55 \\
\hline Turkey & -118 & -137 & -156 \\
\hline El Salvador & 74 & 61 & 47 \\
\hline Sri Lanka & 75 & 66 & 56 \\
\hline Guatemala & 70 & 64 & 57 \\
\hline Cambodia & 191 & 143 & 94 \\
\hline Rest of world & 153 & -504 & $-1,160$ \\
\hline
\end{tabular}

Notes to Table 5: $E V$ and $C V$ denote first-order approximations to equivalent and compensating variation respectively. $W$ is an average of $E V$ and $C V$. See text for details. For each measure we calculate two values, corresponding to the polar assumptions that US residents pay zero and $100 \%$ of transport costs. The numbers in the table are the simple averages of theses two polar assumptions.

The first row reports the net effect of the change, which is a sum over all products and exporters. The next two rows report subtotals over goods which were or were not subject to binding quotas at the end of 2004. The final set of rows reports subtotals by exporting country. 